\title{
THE ANTHROPOGENIC AIR POLLUTION SOURCE IDENTIFICATION IN URBAN AREAS USING SNOW SAMPLING
}

Jovita PILECKA, Scientific Laboratory of Forest and Water Resources, Faculty of Environment and Civil Engineering, Latvia University of Agriculture, Akademijas str. 19, Jelgava, Latvia, jovita.pilecka@1lu.lv (corresponding author)

Inga GRINFELDE, Scientific Laboratory of Forest and Water Resources, Faculty of Environment and Civil Engineering, Latvia University of Agriculture, Akademijas str. 19, Jelgava, Latvia, inga.grinfelde@ gmail.com

Inga STRAUPE, Department of Forest Management, Forest Faculty, Latvia University of Agriculture, Akademijas str. 19, Jelgava, Latvia, inga.straupe@llu.lv

Oskars PURMALIS, Department of Environmental Science, Faculty of Geography and Earth Sciences, Latvia University, Jelgavas str. 1, Riga, Latvia, oskars.purmalis@lu.lv

\begin{abstract}
The anthropogenic sources of air pollution such as transport, energetics, household heating and industry generate different trace element footprint. The urban planning is one of tool to reduce air pollution with trace elements.

The aim of this study is to identify air pollution sources in Jelgava city using trace elements. The snow sampling were collected during January and February 2017. The January snow samples characterise average Jelgava city air pollution. However, February characterises intensive tourism impact on total air quality of Jelgava city.

The snow samples were analysed using inductively coupled plasma spectrometer (ICP-OES).

The data analysis consists of three stages. First, data verification and development of waste burning; burning of oil and fossil materials; wastewater treatment and utilisation of sewage sludge; transport; metal industry and fireworks typical pollution trace element data sets. Second, the cluster analysis of each data set, by developing three groups of pollution level for each pollution source. Third the results of clusters were analysed using GIS, and the areas with different air pollution risks were identified.

The results show strong evidence of transport and household impact on air quality.
\end{abstract}

Keywords: anthropogenic air pollution; inductively coupled plasma spectrometer (ICP-OES).

\section{INTRODUCTION}

The human population is grooving, and more than 70\% will live in urban areas after 2050 (UNESCO 2008). The anthropogenic pressure on environment response in air pollution of the urban regions. There is much research done to identify $\mathrm{NOx}, \mathrm{CO}_{2}$ and $\mathrm{O}_{3}$ impact on human health (Kampa and Castanas, 2008). Trace elements such as $\mathrm{Cu}, \mathrm{Zn}, \mathrm{Li}$, Mo, $\mathrm{Pb}, \mathrm{Ag}, \mathrm{Bi}, \mathrm{B}, \mathrm{Sb}, \mathrm{Sn}, \mathrm{Cd}, \mathrm{Au}, \mathrm{Pt}$ and Pd are associated with anthropogenic air pollution (Veysseyre et al. 2001). The different air pollution sources give different chemical trace elements footprint. The waste burning is associated with many trace elements such as Ag, Al, Ca, K, Fe, Ti, Zn, S, Pb, Cu, Cd, Mn, P, Cr, Sn (Veysseyre et.al. 2001; Rodella et.al. 2017; Gao et. al. 2017; Pacyna et al. 2001). The burning of oil and fossil materials pollute the air with Pb, Zn, Cr, Co, V, Ni, $\mathrm{Sb}, \mathrm{Fe}, \mathrm{Mn}, \mathrm{Cu}, \mathrm{Sn}, \mathrm{As}, \mathrm{Cd}$ (Pacyna et al. 2001). The wastewater treatment and sewage sludge utilisation are associated with $\mathrm{Pb}, \mathrm{Zn}, \mathrm{Cu}, \mathrm{Cd}, \mathrm{Cr}$, Ni (Yang et al., 2017; Dou et al., 2017). The transport gives non-point source pollution in the city and accumulates around transport corridors. The trace elements of air pollution by transport are $\mathrm{Pb}, \mathrm{Cu}, \mathrm{Cr}, \mathrm{Sn}, \mathrm{Sb}$ (Pacyna et al. 2001). The industrialisation generates air pollutants trace elements such as $\mathrm{Pb}, \mathrm{Zn}, \mathrm{N}, \mathrm{Cu}, \mathrm{Cd}$ (Pacyna et al. 2001). The additional air pollution source is firework especially in big cities after New Year and other events (Feng et al. 2016; Zang et al. 2017).

The aim of this study is to identify risk areas in Jelgava city where is the highest risks of trace elements in air and give a suggestion for air quality improvement in urban areas.

\section{MATERIALS AND METHODS}

The method of snow sampling and the methodology of trace element analysis is described by Pilecka et al. 2017. The simple statistics of trace elements identified in January snow samples are presented in table 1 . The high deviation show $\mathrm{Zn} ; \mathrm{Cu}$ and $\mathrm{Mg}$. The very low deviation is $\mathrm{P} ; \mathrm{Li} ; \mathrm{Al}$; Co etc.

Copyright (C) 2017 The Authors. Published by Aleksandras Stulginskis University. This is an open-access article distributed under the terms of the Creative Commons Attribution License (CC-BY 4.0), which permits unrestricted use, distribution, and reproduction in any medium, provided the original author and source are credited. 
Table 1. The simple statistics of identified trace elements in January snow samples

\begin{tabular}{|c|c|c|c|c|c|c|c|c|c|}
\hline & & & & & & & & \\
\end{tabular}

The simple statistics of trace elements identified in February is presented in table 2. The February snow samples show higher concentrations of trace elements, for example, $\mathrm{Zn}$; Mn; Ti and Ba.

Table 2. The simple statistics of identified trace elements in February snow samples

\begin{tabular}{|c|c|c|c|c|c|c|c|c|c|}
\hline 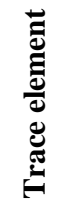 & 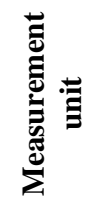 & 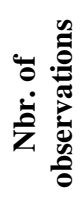 & 㤩 & $\begin{array}{l}\text { 音 } \\
\text { 竞 } \\
\text { 离 }\end{array}$ & 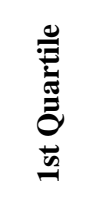 & 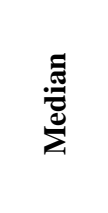 & 窇 & 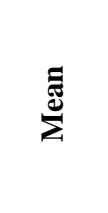 & 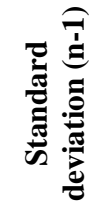 \\
\hline $\mathrm{Cd}$ & $\mathrm{mkg} / \mathrm{l}$ & 63 & 0.19 & 0.39 & 0.19 & 0.19 & 0.19 & 0.21 & 0.05 \\
\hline $\mathrm{Cu}$ & $\mathrm{mkg} / \mathrm{l}$ & 63 & 3.71 & 150.44 & 12.10 & 14.59 & 24.43 & 26.50 & 32.51 \\
\hline $\mathrm{Pb}$ & $\mathrm{mkg} / \mathrm{l}$ & 63 & 1.52 & 31.88 & 5.33 & 8.21 & 15.60 & 11.30 & 8.40 \\
\hline $\mathrm{Ca}$ & $\mathrm{mg} / \mathrm{l}$ & 63 & 2.69 & 259.63 & 14.54 & 26.19 & 41.37 & 41.25 & 55.48 \\
\hline $\mathrm{Mg}$ & $\mathrm{mg} / \mathrm{l}$ & 63 & 0.73 & 118.46 & 5.78 & 11.24 & 16.86 & 17.16 & 25.21 \\
\hline $\mathrm{Na}$ & $\mathrm{mg} / \mathrm{l}$ & 63 & 0.66 & 65.65 & 1.79 & 6.13 & 22.18 & 13.97 & 16.76 \\
\hline $\mathrm{Fe}$ & $\mathrm{mg} / \mathrm{l}$ & 63 & 0.10 & 14.60 & 1.03 & 1.43 & 2.21 & 2.28 & 3.09 \\
\hline $\mathrm{Zn}$ & $\mathrm{mkg} / \mathrm{l}$ & 63 & 32.26 & 680.60 & 66.48 & 101.90 & 145.85 & 150.28 & 170.19 \\
\hline $\mathrm{Ni}$ & $\mathrm{mkg} / \mathrm{l}$ & 63 & 0.64 & 11.75 & 1.25 & 1.61 & 2.46 & 2.44 & 2.44 \\
\hline $\mathrm{Cr}$ & $\mathrm{mkg} / \mathrm{l}$ & 63 & 0.15 & 14.03 & 1.29 & 1.88 & 2.68 & 2.84 & 3.15 \\
\hline $\mathrm{Mn}$ & $\mathrm{mkg} / \mathrm{l}$ & 63 & 25.82 & 983.60 & 80.94 & 122.36 & 156.21 & 165.23 & 201.35 \\
\hline $\mathrm{K}$ & $\mathrm{mg} / \mathrm{l}$ & 63 & 0.15 & 1.91 & 0.39 & 0.49 & 0.72 & 0.65 & 0.45 \\
\hline As & $\mathrm{mkg} / \mathrm{l}$ & 63 & 1.90 & 3.46 & 1.90 & 1.90 & 1.90 & 2.03 & 0.35 \\
\hline $\mathrm{Co}$ & $\mathrm{mkg} / \mathrm{l}$ & 63 & 0.22 & 7.47 & 0.52 & 0.85 & 1.17 & 1.17 & 1.50 \\
\hline $\mathrm{Li}$ & $\mathrm{mkg} / \mathrm{l}$ & 63 & 0.14 & 9.61 & 0.52 & 0.84 & 1.11 & 1.33 & 2.00 \\
\hline $\mathrm{Sr}$ & $\mathrm{mkg} / \mathrm{l}$ & 63 & 3.77 & 173.51 & 14.51 & 26.50 & 31.98 & 32.94 & 36.10 \\
\hline $\mathrm{Ti}$ & $\mathrm{mkg} / \mathrm{l}$ & 63 & 2.21 & 192.03 & 14.00 & 20.75 & 28.27 & 28.06 & 38.83 \\
\hline $\mathrm{Tl}$ & $\mathrm{mkg} / \mathrm{l}$ & 63 & 0.78 & 0.80 & 0.80 & 0.80 & 0.80 & 0.80 & 0.00 \\
\hline $\mathrm{Ba}$ & $\mathrm{mkg} / \mathrm{l}$ & 63 & 7.38 & 275.31 & 22.32 & 34.19 & 61.35 & 56.98 & 67.66 \\
\hline $\mathrm{V}$ & $\mathrm{mkg} / \mathrm{l}$ & 63 & 0.43 & 13.52 & 1.17 & 1.77 & 2.39 & 2.30 & 2.73 \\
\hline $\mathrm{Al}$ & $\mathrm{mg} / \mathrm{l}$ & 63 & 0.06 & 3.95 & 0.42 & 0.51 & 0.66 & 0.70 & 0.81 \\
\hline $\mathrm{P}$ & $\mathrm{mg} / \mathrm{l}$ & 63 & 0.03 & 1.89 & 0.13 & 0.20 & 0.29 & 0.31 & 0.43 \\
\hline $\mathrm{Sb}$ & $\mathrm{mkg} / \mathrm{l}$ & 63 & 1.30 & 3.52 & 1.30 & 1.30 & 1.40 & 1.53 & 0.53 \\
\hline
\end{tabular}


In Jelgava, there were identified six possible sources of trace elements: waste burning; burning of oil and fossil materials; wastewater treatment and utilisation of sewage sludge; transport; metal industry and fireworks. The trace elements of each anthropogenic air pollution source used in data analysis are presented in table 3.

Table 3 The trace elements used in Hierarchical Agglomerative Cluster Analysis

\begin{tabular}{|c|c|c|c|c|}
\hline Air pollution source & $\begin{array}{c}\text { Used trace elements } \\
\text { in January }\end{array}$ & $\begin{array}{c}\text { Code of January } \\
\text { cluster analysis }\end{array}$ & $\begin{array}{c}\text { Used trace elements in } \\
\text { February }\end{array}$ & $\begin{array}{c}\text { Code of February } \\
\text { cluster analysis }\end{array}$ \\
\hline Waste burning & $\begin{array}{c}\mathrm{Cu} ; \mathrm{Pb} ; \mathrm{Ca} ; \mathrm{Fe} ; \mathrm{Zn} ; \\
\mathrm{Cr} ; \mathrm{Mn} ; \mathrm{Ti} ; \mathrm{Al} ; \mathrm{P} ; \mathrm{K}\end{array}$ & J_W_B & $\begin{array}{c}\mathrm{Cd} ; \mathrm{Cu} ; \mathrm{Pb} ; \mathrm{Ca} ; \mathrm{Fe} ; \mathrm{Zn} ; \\
\mathrm{Cr} ; \mathrm{Mn} ; \mathrm{K} ; \mathrm{Ti} ; \mathrm{Al} ; \mathrm{P}\end{array}$ & F_W_B \\
\hline $\begin{array}{c}\text { Burning of oil and } \\
\text { fossil materials }\end{array}$ & $\begin{array}{c}\mathrm{Cu} ; \mathrm{Pb} ; \mathrm{Fe} ; \mathrm{Zn} ; \mathrm{Ni} ; \\
\mathrm{Cr} ; \mathrm{Mn} ; \mathrm{Co}\end{array}$ & J_F & $\begin{array}{c}\mathrm{Cd} ; \mathrm{Cu} ; \mathrm{Pb} ; \mathrm{Fe} ; \mathrm{Zn} ; \mathrm{Ni} ; \\
\mathrm{Cr} ; \mathrm{Mn} ; \mathrm{As} ; \mathrm{Co} ; \mathrm{V} ; \mathrm{Sb}\end{array}$ & F_F \\
\hline $\begin{array}{c}\text { Wastewater treatment } \\
\text { and utilisation of } \\
\text { sewage sludge }\end{array}$ & $\mathrm{Cu} ; \mathrm{Pb} ; \mathrm{Zn} ; \mathrm{Ni} ; \mathrm{Cr}$ & J_W_W & $\mathrm{Cd} ; \mathrm{Cu} ; \mathrm{Pb} ; \mathrm{Zn} ; \mathrm{Ni} ; \mathrm{Cr}$ & $\mathrm{F} \_W$ \\
\hline Transport & $\mathrm{Cu} ; \mathrm{Pb} ; \mathrm{Cr}$ & J_TR & $\mathrm{Cu} ; \mathrm{Pb} ; \mathrm{Cr} ; \mathrm{Sb}$ & $\mathrm{F} ; \mathrm{TR}$ \\
\hline Metal industry & $\mathrm{Cu} ; \mathrm{Pb} ; \mathrm{Zn} ; \mathrm{Ni}$ & J_M & $\mathrm{Cd} ; \mathrm{Cb} ; \mathrm{Zn} ; \mathrm{Ni}$ & $\mathrm{M}$ \\
\hline Firework & $\begin{array}{c}\mathrm{Cu} ; \mathrm{Pb} ; \mathrm{Ca} ; \mathrm{Mg} ; \mathrm{Na} ; \\
\mathrm{Fe} ; \mathrm{Zn} ; \mathrm{Ni} ; \mathrm{Mn} ; \mathrm{Sr} ; \\
\mathrm{Ba} ; \mathrm{Al} ; \mathrm{K}\end{array}$ & J_FW & $\begin{array}{c}\mathrm{Cu} ; \mathrm{Pb} ; \mathrm{Ca} ; \mathrm{Mg} ; \mathrm{Na} ; \mathrm{Fe} ; \\
\mathrm{Zn} ; \mathrm{Mn} ; \mathrm{K} ; \mathrm{Sr} ; \mathrm{Ba} ; \mathrm{Al}\end{array}$ \\
\hline
\end{tabular}

The values of trace elements were standardised before cluster analysis to give equal weights to all trace elements (Milligan \& Cooper, 1988).

Hierarchical Agglomerative Cluster Analysis was used to classify snow samples into groups using similarities (AlOdaini et al. 2012; Farmki et al. 2012; Zhang 2013). Totally 12 Hierarchical Agglomerative Cluster Analysis was made. The cluster analysis results for each analysing group were divided into three pollution levels according to cluster centroid coordinates:

1. Low pollution -1 (green) if total sum of standardised centroid coordinates is $<0$

2. Middle pollution -2 (yellow) if total sum of standardized centroid coordinates is $0<5$

3. High pollution -3 (red) if total sum of standardized centroid coordinates is $>5$

The weights of each monitoring point were summarised and according to the total sum of clustering results were divided risk groups of air pollution with trace elements.

1. Clean air - total sum of clustering results equal to 12 (green)

2. Low risk - total sum of clustering results 13 to 17 (yellow)

3. Middle risk - total sum of clustering results 18 to 23 (orange)

4. High - risk total sum of clustering results 24 and higher (read)

The GIS map with risk areas was created to show air pollution risk level in analysed areas of Jelgava.

\section{RESULTS}

The Hierarchical Agglomerative Cluster Analysis results according to the total sum of standardised centroid coordinates are presented in table 4 . The results show five clean monitoring points in Jelgava city. All five monitoring points at all clustering results were in some cluster with reference monitoring point - Mezciems. The high air pollution from waste burning during January and February were identified in three monitoring points. The burning of oil and fossil materials show more monitoring points with high pollution February. The air pollution with trace elements from wastewater treatment and utilisation of sewage sludge were high in few monitoring points. January and February. The transport is none of the air pollutions with trace element source, and high air pollution is identified in three points each month. The air pollution with trace elements from metal industry is high in two monitoring points. The air pollution with trace elements from fireworks is identified in January and February at several monitoring points.

The spatial distribution of air pollution risk level of monitoring points in Jelgava is presented in figure 1. There are four monitoring points with a high risk of air pollution with trace elements. The train station is one of high risk area, the intensive cargo flow through Jelgava city and road infrastructure intensify the risk of air pollution with trace elements. As it is represented in table 4 January and February have equally high air pollution in train station area. The Tervetes street and Pavasara street area are with a high risk of air pollution with trace elements. The area is characterised by the individual housing and closed landscape. As well as individual heating systems with different burning materials from wood and coal to plastic and paper can intensify air pollution with trace elements risk. The Aviacijas street and Lacplesa street monitoring point are situated between industrial and living area show a high risk of air pollution with trace elements. The Institute street and Rig a street monitoring point show high air pollution risk with trace elements during February. This can be explained by intensive anthropogenic air pollution with trace elements during Ice Sculpture festival. The cleanest areas are situated in open landscape with open water bodies. For example, Rigas street and Brivibas street monitoring point is situated close to gasoline station between two mine streets in Jelgava with intensive transport flow, but there is relatively clean air because of open landscape and a short distance to Lielupe river. 
Table 4 The pollution levels according to total sum of cluster centroid coordinates

\begin{tabular}{|c|c|c|c|c|c|c|c|c|c|c|c|c|}
\hline Sample & $\begin{array}{l}n_{1} \\
3_{1} \\
n_{1}\end{array}$ & $\begin{array}{l}\infty_{1} \\
3^{\prime} \\
\mathbf{I}^{\prime}\end{array}$ & $\stackrel{L^{\prime}}{\sigma^{\prime}}$ & $I_{I}$ & $\begin{array}{l}3 \\
3 \\
3 \\
b_{1}\end{array}$ & $\begin{array}{l}3 \\
3 \\
3 \\
1\end{array}$ & 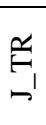 & $\begin{array}{l}\text { 哠 } \\
\text { I }\end{array}$ & 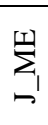 & $\sum_{I}^{M}$ & $\underset{\mid l}{3}$ & 盛 \\
\hline Viskalu str./Lietuvas str. & 2 & 1 & 1 & 1 & 1 & 1 & 1 & 1 & 1 & 1 & 2 & 1 \\
\hline Platones str. /Lietuvas str. & 3 & 2 & 2 & 3 & 2 & 1 & 2 & 1 & 1 & 1 & 2 & 3 \\
\hline Savienibas str./Lietuvas str. & 2 & 1 & 2 & 1 & 2 & 1 & 2 & 1 & 1 & 1 & 2 & 1 \\
\hline $\begin{array}{l}\text { Train station } \\
\end{array}$ & 3 & 3 & 3 & 3 & 2 & 3 & 2 & 3 & 2 & 3 & 3 & 3 \\
\hline Tervetes str./railway & 3 & 1 & 2 & 1 & 1 & 1 & 1 & 1 & 1 & 1 & 3 & 1 \\
\hline Rupniecības str. / Tervetes str. & 1 & 2 & 1 & 3 & 1 & 2 & 1 & 1 & 1 & 2 & 1 & 3 \\
\hline Tervetes str./ Pavasara str. & 3 & 3 & 3 & 1 & 3 & 2 & 3 & 1 & 3 & 2 & 3 & 2 \\
\hline Liela str./Kalpaka str. & 1 & 2 & 1 & 1 & 2 & 2 & 1 & 1 & 2 & 2 & 1 & 1 \\
\hline Liela str./Dobeles str. & 1 & 2 & 1 & 1 & 1 & 2 & 1 & 3 & 1 & 2 & 1 & 1 \\
\hline Aspazijas str./ Asteru str. & 1 & 1 & 1 & 1 & 1 & 1 & 1 & 1 & 1 & 1 & 1 & 1 \\
\hline Dobeles str./ Satiksmes str. & 3 & 1 & 2 & 1 & 2 & 1 & 2 & 1 & 1 & 1 & 3 & 1 \\
\hline Satiksmes str./ Ganibu str. & 2 & 2 & 1 & 1 & 1 & 2 & 1 & 1 & 1 & 2 & 2 & 1 \\
\hline Ausekla str./ Blaumana str. & 1 & 1 & 1 & 1 & 1 & 2 & 1 & 1 & 1 & 2 & 1 & 1 \\
\hline Pasta island & 1 & 1 & 1 & 1 & 1 & 1 & 1 & 1 & 1 & 1 & 1 & 1 \\
\hline Rigas str. / Brivibas str. & 1 & 1 & 1 & 1 & 1 & 1 & 1 & 1 & 1 & 1 & 1 & 1 \\
\hline Prohorova str./ Neretas str. & 1 & 1 & 1 & 1 & 1 & 1 & 1 & 1 & 1 & 1 & 1 & 1 \\
\hline Garozas str. / Rubenu str. & 1 & 1 & 1 & 1 & 1 & 1 & 1 & 1 & 1 & 1 & 1 & 1 \\
\hline Aviacijas str. /Lacplesa str. & 3 & 2 & 3 & 1 & 3 & 2 & 3 & 1 & 3 & 2 & 3 & 1 \\
\hline Rigas str./Loka str. & 1 & 2 & 1 & 3 & 1 & 2 & 1 & 3 & 1 & 2 & 1 & 1 \\
\hline Instituta str./ Rigas str. & 1 & 3 & 1 & 3 & 1 & 3 & 1 & 3 & 1 & 3 & 2 & 3 \\
\hline Mezciems (the reference) & 1 & 1 & 1 & 1 & 1 & 1 & 1 & 1 & 1 & 1 & 1 & 1 \\
\hline
\end{tabular}

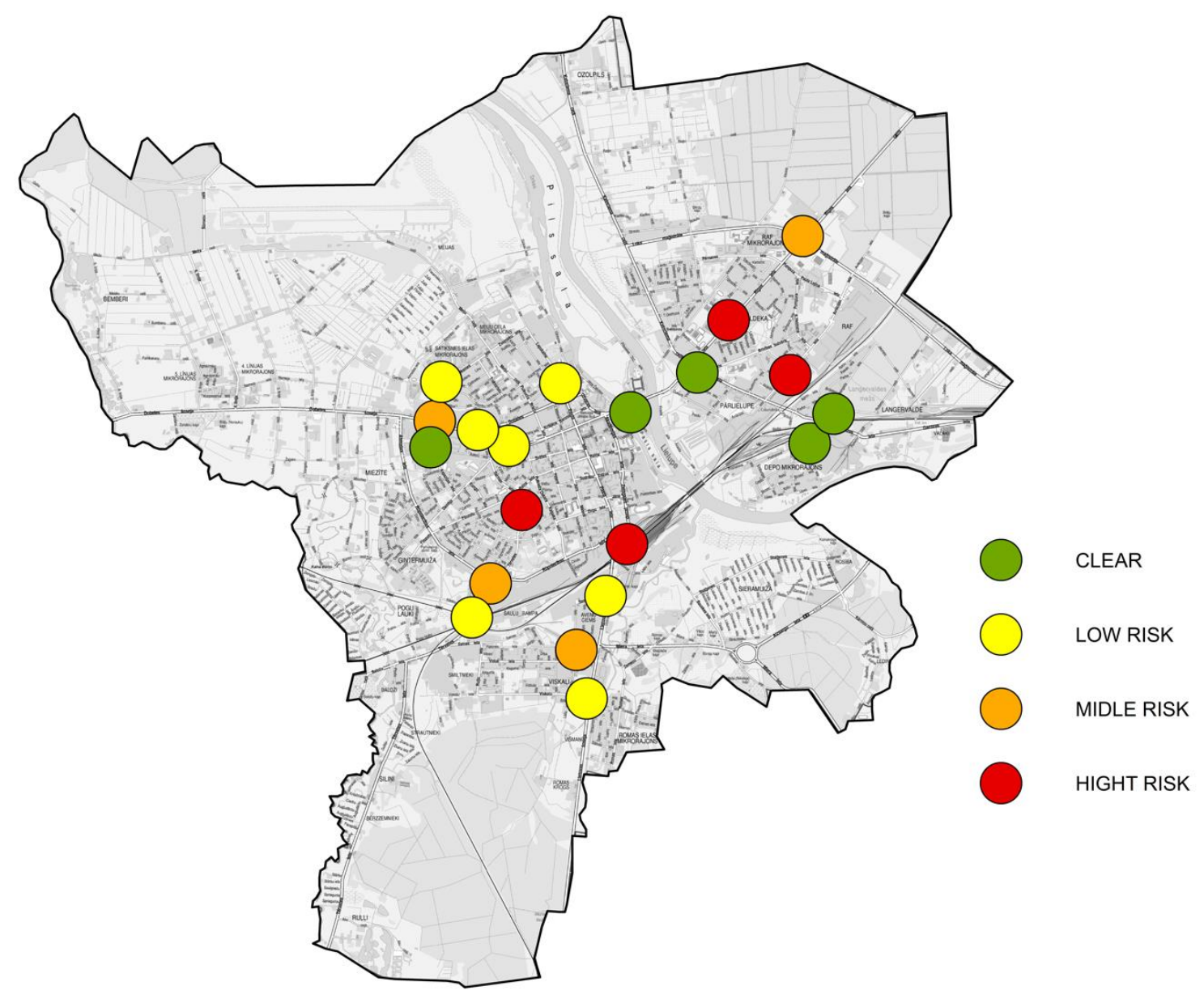

Figure 1. The map of Jelgava with risk intensity of air pollution with trace elements

\section{CONCLUSIONS}

1. The research results highlight the temporal and spatial multidimensionality of air pollution with trace elements in the urban environment. 
2. The results show the positive impact of open urban areas and open water bodies on air quality.

3. The air pollution risk with trace elements is higher in urban canyons and lover in ventilated areas.

\section{REFERENCES}

1. Al-Odaini, N. A., Zakaria, M. P., Zali, M. A., Juahir, H., Yaziz, M. I., \& Surif, S. 2012. Application of chemometrics in understanding the spatial distribution of human pharmaceuticals in surface water. Environmental Monitoring and Assessment, Vol. 184 (11), pp. 6735-6748. https://doi.org/10.1007/s10661-011-2454-3

2. Dou, X., Chen, D., Hu,Y., Feng, Y., Dai, X., Carbonization of heavy metal impregnated sewage sludge oriented towards potential co-disposal. Journal of Hazardous Materials, Vol. 321, pp. 132-145. https://doi.org/10.1016/j.jhazmat.2016.09.010

3. Farmaki, E. G, Thomaidis, N. S, Simeonov, V. and Efstathiou, C. E. 2012. A comparative chemometric study for water quality expertise of the Athenian water reservoirs. Environmental Monitoring Assessment, Vol. 184, pp. 7635-7652. https://doi.org/10.1007/s10661-012-2524-1

4. Feng, J., Yu, H., Su, X., Liu, S., Li, Y., Pan, Y., C, Sun, J.H. 2016. Chemical composition and source apportionment of PM2.5 during Chinese Spring Festival at Xinxiang, a heavily polluted city in North China: Fireworks and health risks. Atmospheric Research, Vol. 182, pp. 176-188. https://doi.org/10.1016/j.atmosres.2016.07.028

5. Gao, X., Yuan, B. Yu, Q.L Brouwers, H.J.H. 2017. Characterization and application of municipal solid waste incineration (MSWI) bottom ash and waste granite powder in alkali activated slag. Journal of Cleaner Production, Vol. 164, pp. 410-419. https://doi.org/10.1016/j.jclepro.2017.06.218

6. Kampa, M., Castanas, E. 2008. Human health effects of air pollution. Environmental Pollution, Vol. 151, Iss. 2, pp. 362-367 https://doi.org/10.1016/j.envpol.2007.06.012.

7. Milligan, G.W., Cooper, M.C. 1988. A study of standardization of variables in cluster analysis. Journal of Classification, Vol. 5, pp. 181-204. https://doi.org/10.1007/BF01897163

8. Pacyna, E. G., Pacyna, J. M., Pirrone, N. 2001. European emissions of atmospheric mercury from anthropogenic sources in 1995. Atmospheric Environment, Vol. 35(17), pp. 2987-2996. https://doi.org/10.1016/S1352-2310(01)00102-9.

9. Pilecka, J., Grīnfelde, I., Valujeva, K., Straupe, I., Purmalis, O. 2017. Heavy metal concentration and distribution of snow and Lichea samples in urban area: Case study of Jelgava. International Multidisciplinary Scientific GeoConference Surveying Geology and Mining Ecology Management, SGEM, Vol. 17 (41), pp. 459-466. https://doi.org/10.5593/sgem2017/41/S19.058

10. Rodella, N., Bosio, A., Dalipi, R., Zacco, A., Borgese, L., Depero, L.E., Bontempi, E. 2017. Waste silica sources as heavy metal stabilizers for municipal solid waste incineration fly ash. Arabian Journal of Chemistry, Vol. 10, pp. 3676-3681. https://doi.org/10.1016/j.arabjc.2014.04.006

11. Veysseyre, A., Moutard, K., Ferrari, C., Van de Velde, K., Barbante, C., Cozzi, G., Capodaglio, G., Boutron, C. 2001. Heavy metals in fresh snow collected at different altitudes in the Chamonix and Maurienne valleys, French Alps: initial results. Atmospheric Environment, Vol. 35, pp. 415-425. https://doi.org/10.1016/S1352-2310(00)00125-4

12. Yang, T., Huang, H., Lai, H. 2017. Pollution hazards of heavy metals in sewage sludge from four wastewater treatment plants in Nanchang, China. Transactions of Nonferrous Metals Society of China, Vol. 27, pp. 2249-2259. https://doi.org/10.1016/S1003$\underline{6326(17) 60251-6}$

13. Zhang, J., Yang, L., Chen, J., Mellouki, A., Jiang, P.,Gao, Y., Li, Y., Yang, Y., Wang, W. 2017. Influence of fireworks displays on the chemical characteristics of PM2.5 in rural and suburban areas in Central and East China. Science of the Total Environment, Vol. 578, pp. 476-484. https://doi.org/10.1016/j.scitotenv.2016.10.212

14. Zhang, X., Jiang, H. and Zhang, Y. 2013. Spatial distribution and source identification of persistent pollutants in marine sediments of Hong Kong. Environmental Monitoring Assessment, Vol. 185, pp. 4693-4704. https://doi.org/10.1007/s10661-012-2897-1 